\title{
Muntlig historia: mer än vetenskap?
}

\author{
Av Attila Lajos
}

\section{Vad är muntlig historia?}

Muntlig historia är en historia som är skriven med levande muntliga berättelser som källor, källor som står i direkt kontakt med historikern, som själv är med och med sina frågor och rentav skapar dessa berättelser.

Vittnespsykologins slutsatser om ögonvittnens mycket individuella sätt att återge sina iakttagelser tillhör vardagskunskapen idag. Ändå anser muntliga historiker att dessa källor är fullt användbara och fortsätter skapa nya källor, oftast genom intervjuer. Dessa intervjuer analyseras sedan, som om de skulle innehålla något genuint, som inte hade förts in, eller som inte hade blivit förvrängt, när dessa källor skapades. Ett högst ovanligt tillvägagångssätt alltså, som hos den klassiskt skolade historikern väcker allvarliga frågor om slutsatsernas förmodade objektivitet. Man börjar verkligen fråga sig: Behövs muntlig historia? Den ger ju inga fakta utan bara subjektiva uppfattningar och föreställningar. Men är de muntliga källorna inte lika viktiga som andra källor? Finns det egentligen någon historia utan muntlig historia? Inga fakta finns ju i sig själva, utan bara som uppfattningar och föreställningar i subjektens medvetande och ofta har de uttryckts muntligt först.

Svårast är att försvara dessa källor mot angrepp som gäller deras validitet och reliabilitet. Jag anar att de historiker som fortfarande ställer etablerade vetenskapliga anspråk på historieskrivningen håller de muntliga källorna för ganska värdelösa. Dessa är - säger man - för osäkra och subjektiva för att kunna användas som intersubjektiva vetenskapliga sanningskriterier, ett anspråk som varje vetenskaplig aktivitet måste leva upp till för att accepteras - och jag kan i viss mån hålla med om det.

För att kunna försvara ståndpunkten att muntlig historia är lika berättigad som annan historieskrivning, måste vi studera de begrepp som ställs emot denna och hur dessa begrepp har utvecklats, ty härvidlag har stora förändringar skett under de senaste decennierna. Historia, muntlig historia, vetenskap och det problematiska i deras sammankoppling blev aktuella frågor därför att ett av det moderna västerländska samhällets grundbegrepp, vetenskap, förlorat sin tydliga definition, och därmed också sina trygghetsgivande egenskaper.

\section{Vart har den trygghetsgivande vetenskapen tagit vägen?}

Det verkar på något svårförklarligt sätt vara så att kvantfysikens häpnadsväckande resultat bröt igenom den kartesianska muren som hade omringat det vetenskapliga samhällets tänkande fram till mitten av 1900-talet. Den logiska positivismen, som hade utgjort detta tänkandes höjdpunkt räckte inte längre. Fysiken upptäckte att de subatomära partiklarna - grunden för den materiella verkligheten - inte verkar finnas i sig själva, utan bara som en relation mellan sig själva och vår intentionalitet att hitta och mäta dem. Osäkerhetsprincipen som 
utvecklades av Heisenberg redan på 1930-talet visade att det var omöjligt att observera de subatomära partiklarna utan att direkt påverka dem med observationsinstrumenten. ${ }^{1}$ Det gick inte längre att hitta och analysera delarna så som de var för att sedan beskriva helheten. Delarna föreföll inte längre ha egna egenskaper, utan de fanns bara som en relation mellan det som finns och den som observerar. Man upptäckte - och accepterade så småningom - att vetenskapsmannen påverkade sitt undersökningsobjekt redan när han eller hon riktade sökarljuset på det, och att denna påverkan var ofrånkomligt. Därmed försvann möjligheterna till den objektivitet som var den gamla vetenskapsuppfattningens mest grundläggande begrepp. Det var denna objektivitetsuppfattning som gjorde det möjligt att tro på den absoluta sanningen - en sanning som vi närmade oss med vetenskapens hjälp. Den gav mening åt den vetenskapliga världsbilden samtidigt som den ställde vetenskapssamhället över moraliska ansvarsfrågor. Denna utopiska vetenskapsuppfattning gjorde att vetenskapen blev som en religion, som ett opium för massan, och vetenskapsmännen dyrkades som denna världsfrälsande religions präster, vissa av dem även som ofelbara påvar.

Men nu försvann också den enkla dualistiska strukturen, där människan avbildades som det kunskapssamlande subjektet - en kunskap som troddes motsvara den objektiva världen, föreställd som en mekanism som alltid uppträdde på samma sätt under samma villkor, oberoende av observatören. Den fick lämna plats åt en mycket mer osäker och ostrukturerad uppfattning där människan - även vetenskapsmannen - träder in på scenen både som subjekt och objekt, där sanningarna inte längre är oberoende av observatören utan lyder under dennes skapande förmåga. Sanningarnas allmängiltighet tids- och rumsbegränsades, vilket ledde till att man i vissa pragmatiska delar av världen bestämde sig för att strunta i sanningen så länge man hade användbar kunskap just för ögonblicket (instrumentalism, behaviorism). Snart visade sig denna typ av kunskap vara mer till skada än till nytta, ty den upptäcker falska, icke existerande och vilseledande orsakssamband som mer täcker än upptäcker något.

Räddningen verkade finnas i systemteoriernas dialektiska helhetssyn, i det s.k. ekologiska tänkandet där vetenskapen spelar en likvärdig roll med andra delar inom helheten. ${ }^{2}$ Men även detta är problematiskt. Om allting hänger ihop och om man alltid ska försöka angripa problemet i sin helhet, hittar man aldrig den bästa utgångspunkten. Helhetssynen - även om den är sann - har en paralyserande effekt som gör handlingen omöjlig och varje val ansvarslöst. Medvetenheten om att det inte går att veta allting samtidigt och iakttagelsen av att vetenskapliga uppfinningar har oanade konsekvenser gav en väldigt osäker grund för vetenskapen, men den hade samtidigt den sunda effekten att minska den vetenskapliga arrogansen. Vägen var öppen för att slutgiltigt uppge den absoluta objektivismens ideal och inse att sanningarna måste begränsas till vissa tids- och rumsmässiga giltighetsområden och perioder. Och så föddes Kuhns paradigmteori, som säger att giltigheten hos vetenskapliga sanningar kommer

1 För en enkel förklaring av osäkerhetsprincipen se Heisenberg, 1993.

2 "I systemteori finns inte orsak och verkan. Relationer är cirkulära, inte linjära. Det är inte meningsfullt att fokusera enbart på en persons beteende. Allting existerar i ett sammanhang. Absoluta sanningar finns inte, inte heller någon absolut moral... Allting påverkar vartannat hela tiden. Att tänka i orsak och verkan är ett föråldrat synsätt som vi övergett idag. Likaså tanken att det skulle finnas en objektiv moral.”, skriver göteborgstudenten Jan Eriksson i sin examinationsuppgift om Systemteori och socialkonstruktivism - en kritisk granskning, 2003. Se web.telia. com/ u31437000/system.htm\#_Vad_är_systemteori? 
av deras egenskap att passa in i den just gällande världsuppfattningsmosaiken - paradigmet som han kallade det - och är egentligen bara ett resultat av en tyst överenskommelse, där argumentun auktoritas, auktoritetsargumentet, verkar ha varit stark förekommande. ${ }^{3}$

I opposition mot Kuhn, men på något sätt i samma anda - användandet av ett tidsperspektiv - kom Lakatos teorier om research programs. De säger att vetenskapliga teorikomplex - samlade kring några kärnteorier som utgör de ultimata referenspunkterna under en viss tidsperiod - bekräftas främst av deras egenskap att kunna öppna vägar mot framtiden, att fungera som kristallkulor som möjliggör giltiga och användbara predikationer, som i sin tur leder till nya goda och användbara upptäckter och nya program. ${ }^{4}$

Jag anser att något märkligt inträffade i och med accepterandet av dessa teorier. De är långt ifrån bara påpekanden om observationens teoriberoende som förut användes som kritik mot positivismen. Genom införandet av skapande, överenskommelse och tid (historia och framtid) som vetenskapsdefinierande faktorer börjar man segla nära den otrygga irrationalitetens kuster och behovet av kontroll och trygghet är för viktigt för att någonsin uppges. Därför har jag intrycket att medan de ovannämnda teorierna rationellt accepteras av de flesta forskare så lever fortfarande i tysthet tron på möjligheten till objektiva observationer och experiment och tron på den absoluta sanningen som bara vetenskapen leder oss till. Chalmers gör en bra observation när han påpekar att den induktiva (kunskapssamlande) vetenskapsuppfattningen inte är fullständigt vederlagd. ${ }^{5}$ Och tänker vi lite djupare så inser vi att tron på det absoluta - objektiviteten eller sanningen - är en nödvändighet för att hålla igång den relativa rörliga världen. Vilken löpare skulle fortsätta loppet om han visste att mållinjen hela tiden flyttades framåt eller att den kanske redan var bakom honom - eller kanske inte fanns alls? Detta behov av en stillastående mållinje - verklig eller imaginär - är den främsta orsaken till att det gamla vetenskapsidealet som ligger till grund för induktivismen och positivismen fortfarande verkar; detta är orsaken till att det induktiva tänkandet fortfarande är vanligast. Det är en nödvändighet vid praxisens bänkar, ty det ger mening och perspektiv. Det finns bara få som i praktiken vågar ta något annat alternativ på allvar än det som är grundat på observation och experiment.

\section{Vad är historia? Är det vetenskap?}

Historia är ett begrepp som genom sin långa karriär har betraktats och behandlats och skrivits på många olika sätt innan försök gjordes till sammankoppling med det av upplysningen skapade modebegreppet vetenskap. Om vi bortser från den österländska - framför allt indiska - cykliska tidsuppfattningen och den påföljande relativa historielösheten, så har vi i grund och botten två olika perspektiv som karakteriserat historieskrivningen i Västerlandet. Inget av dessa två lyckades definitivt besegra det andra, trots att det ena kan kallas mer vetenskap-

3 Se Kuhn, 1962. I boken framför Kuhn tesen att under en viss given tidsperiod utgår varje vetenskaplig generation (eller samhälle) från ett gemensamt kunskapsunderlag och sätt att tänka, ett paradigm, som alla forskare, medvetet eller omedvetet, refererar till. Detta paradigm bestämmer forskningens inriktning, vilken typ av frågor och metoder man skall använda osv. Ett paradigm ändras genom en vetenskaplig revolution, som skapar ett nytt gemensamt underlag osv.

4 Se Lakatos, 1976 och 1977.

5 Chalmers, 1995. 
ligt och medan det andra är mytiskt-moraliserande, ty vi människor vill både veta sanningen och samtidigt ha någon nytta av denna så kallade sanning.

Skillnaden, enligt min uppfattning, blev att dessa historieskrivningar hade olika ambitioner vad det gäller tiden. Den ena vill låta tiden rulla och använder historia. Den låter dåtiden rulla in i nutiden och nutiden i dåtiden. Den pendlar fram och tillbaka, kopplar samman och behandlar det som vi skulle kalla historiska fakta ganska lätt och elastiskt. Det är en historieskrivning som förklarar med utgångspunkt i "så borde det ha varit"- ställningen och som inte bryr sig så mycket om "hur det faktiskt var". Ändå gör den mer eller mindre anspråk på totalförståelse; och detta utifrån en uppfattning om att vi alltid är likadana. Den utgår från en paradoxal behandling av tiden där dåtid, nutid och framtid förenas i historiemedvetandet, $\mathrm{i}$ ett slags stillastående rörelse som skapar en allestädes närvarande helhetsbild. Den är full av värderingar och låter historikern träda in på den samhälleliga arenan för att ta del och ta sitt ansvar. Naturen och Människan flätas samman och det oförklarliga flätas in i och accepteras som en del av människoödet. Denna linje är den som kan dras från Herodotos och Titus Livius rakt in i medeltiden med sina krönikörer, som sedan används under romantiken och har satt sina spår i dagens postmoderna inställning och historieskrivning.

Den andra vägen - som kom att anses som början till den vetenskapliga metoden - följer den riktning som letar sitt ursprung hos Thukydides och Tacitus och leder fram till positivismen. Den drar skarpare skiljelinjer mellan det förflutna, nutid och framtid. Den försöker hitta förklaringar inom dessa olika tider, försöker förklara inifrån genom att bland annat upptäcka mänskliga intressen, ekonomiska förutsättningar, maktbalanser; med andra ord fakta, som verkade under den specifika perioden, i början bara genom att resonera på det viset, men sedan genom att försöka hitta materiella belägg för sina resonemang. Denna riktning är den som vill ta reda på "hur det faktisk var" och beskriva detta på ett objektivt sätt. Med andra ord på ett sådant sätt att oavsett vem som läser beskrivningen får denne samma tanke, samma bild av det som skedde.

\section{Den objektiva historieskrivningen och den nya vetenskapsfilosofin}

Konstig nog så är den objektiva historieskrivning en märklig ambition, sedd ur den nya vetenskapsfilosofins synvinkel. Om vi tänker lite längre, förutsätter den en viss mekanisk syn på människan, där varje objekt i grunden skapar samma tankeavbildning oavsett vilken individ som kommer i kontakt med det: hindu, bantu eller svensk. Tänker vi vidare inser vi att denna ambition är märklig också därför att den talar om förståelse bara i den ena riktningen: utifrån fakta - som om fakta kunde hittas och framställas utan förståelse. Sedan är även denna ensidiga förståelseriktning stark begränsat, ty objektivitet förutsätter ett slags överindividualitet som inte tillåter vilka tolkningar som helst och på det sättet tar den bort själva historikern. Medan den första historieuppfattningen förklarar historiens gång utifrån starka individer och deras personliga öden försöker den andra riktningen komma bort från individcentreringens slumpmässighet och förklara historiens rörelse genom mekanismer och strukturer som verkar oberoende av individernas vilja. I sina högsta ambitioner försökte representanterna för denna riktning hitta de universella lagar som styr utvecklingen: den tid- 
lösa absoluta sanningen. Denna ambition föll samtidigt med idealvetenskapens fall. Plötsligt upptäcktes att allt är historia: berättelser i och om tiden. Men frågan om vad som håller igång och styr Rörelsen (den s.k. utvecklingen i historiens fall) - som är en förutsättning för tiden - har ännu inte besvarats. För att besvara den följde historievetenskapen storbror naturvetenskapen och började gå på djupet för att utreda kaoset: de subatomära partiklarna och kvantfysiken i naturvetenskapens fall, individen och muntlig historia i Historiens fall. ${ }^{6}$ Det är mycket osäkra grunder i båda fallen. Men den fasta mållinjen är den samma bara att den inte längre är en linje. Det är en punkt som man kan närma sig från alla riktningarna. Det paradoxala är bara det att punkten, som vi alla vet, inte har några dimensioner.

\section{Muntlig historia: mer än vetenskap?}

Alltsedan Allan Nevin 1948 startade sin Oral History-projekt på Columbia University så har en mängd publikationer som bygger på muntlig historia sett dagens ljus. Detta beror rimligen just på den förändrade synen på vetenskap och historia och besvikelsen över att man med de klassiska metoderna och teorierna misslyckats med att förklara historiens gång.

Hur individerna - som i slutändan är bärare av historien - är kopplade till de stora formationerna och institutionerna, hur och varför individerna bär sig åt på ett strukturerat sätt och ändå bevarar sin individualitet och oförutsägbarhet, hur kontrollerbara strukturer och förutsägbara formationer bildas ur dessa oförutsägbara enheter - det är frågor som fortfarande är obesvarade. Eftersom det struktursökande ovanifrånperspektivet gav luddiga svar där individerna inte fanns med - trots att det är de som alltid utgör den konkreta och berörbara verkligheten - började historikerna, i demokratiseringens namn, skriva ur ett underifrånperspektiv. Den lägsta nivån - den mest grundläggande alltså - i detta underifrånperspektiv är just individen. Muntlig historia är född ur strävan att nå denna nivå, och dess målsättning är att uppteckna och bevara de individuella minnena som grundläggande källor för historieskrivningen. Michael Frisch formulerade frågor som ställs till historien i allmänhet och den muntliga historien i synnerhet. Han beskriver den muntliga historiens förtjänster på följande sätt:

What happens to experience on the way to becoming memory? What happens to experience on the way to becoming history? ....what is the relationship of memory to historical generalization? These questions, so basic to thinking about how culture and individuality interact over time, are the sort of questions that oral history is peculiarly, perhaps uniquely, able to penetrate.

Att frågan om huruvida historia skriven ur detta lägsta perspektiv är vetenskap eller inte fortfarande är omdiskuterad beror på den säkerhet och trygghet som en vetenskap grundad på positiva fakta, framställda genom induktiv observation och beräkningar eller upprepbara experiment ger. Men utifrån den nya vetenskapsfilosofiska inställningen är frågan meningslös. Vetenskapen beskrivs inte längre som den enda vägen som leder till upptäckandet av de tidlösa sanningarna utan som en djupt mänsklig aktivitet för bättre förståelse av enheten och

6 "History in spite of the academic conventions, remains memory”, skriver Herberth Hirsch (1995). Även s.k. "shared memories” berättas av individer. Vissa av dem är historiker.

7 Perks \& Thompson, 1998:34. 
samspelet mellan människan och hennes tillvaro - likställd med filosofin, konsten och litteraturen. I detta perspektiv öppnar varje individuell berättelse nya infallsvinklar. Herbert Hirsch skriver: "Whatever lies in the human heart remains an enigma."8 Jag håller med honom och hoppas att det så förblir för det mänskliga livets skull.

Samtidigt är jag - liksom Michael Frisch och många andra - övertygad om att muntlig historia är det bästa sättet att underifrån öppna vägen mot en bättre förståelse av samspelet mellan aktör och struktur. Genom muntlig historia kan historikern komma åt det sätt varpå folk strukturerar sin tillvaro, hur "people (are) trying to make a sense of their lives."9 Det handlar om mycket mer än att bara ta reda på fakta. Emellertid är en ganska exakt datering och beskrivning av fakta utifrån flera källor också viktig. Att med största möjliga precision ta reda på "hur det faktisk var" är inte bara en verifieringsprocedur utan också en strukturerande kunskap i vilken den subjektiva tiden kan speglas och tolkas. ${ }^{10}$ Metodologiskt sett är denna faktiska förkunskap viktig för att historikern skall kunna ställa de rätta frågorna och leda intervjun. Här har vi en av de känsligaste och intressante frågorna om muntlig historia och dess huvudmetod: intervjun. Det handlar om den muntliga historiens skapande egenskap eller karaktär: man kan säga att i intervjuprocessen skapar historikern sina data i samspel med den intervjuade. Detta är en aspekt som anses vara utomordentligt viktig i alla de arbeten som behandlar muntlig historia som jag har läst. Man bör betrakta intervjun som ett samspel, där båda deltagarna gör varierande intryck på motparten, ett samspel laddat av symboler och specifika kulturella yttringar och föreställningar. I samspelet skapas en situation som aldrig kommer att upprepas, blixtföreställningar som genererar spontana svar utifrån katarriska upplevelser, som ibland öppnar helt nya infallsvinklar. Allt detta leder till tanken på hur föreställningar, uppfattningar och sedan den mänskliga verkligheten skapas ur interaktionen i specifika situationer, i det stora utrymmet mellan slump och nödvändighet. Medan den traditionella historien bara var kapabel att beskriva den reifierade delen av detta samspel mellan den meningssökande människan och tillvaron och dess ofta svårtkontrollerbara slumpmässighet, så kan man med hjälp av muntlig historia komma åt delar som hittills varit gömda för historieskrivningen, delar där även alternativa verkligheter kan diskuteras. ${ }^{11}$ Genom sin relationsfokuserade karaktär kan muntlig historia rikta uppmärksamheten på den livsvärldskonstruerande aktören, på medvetandeinnehållet om den yttre, inskränkande världen och relationen till denna. Denna relation initierar, ger form, fullbordar den verklighetsskapande handlingen och inkorporerar sedan den nya världen genom att tänka på den ur den utförda och kommande handlingens perspektiv. Detta är nuets ögonblicksperspektiv när

8 Hirsch, 1995:154.

9 Perks \&Thompson, 1998:35.

10 Ett bra exempel på denna tolkning och förklaring av hur den subjektiva tiden gestaltas hittar vi hos Portellis beskrivning av den italienska arbetarhjälten Luigi Trastullis död (Portelli, 1991). Trastulli dödades av polisen 1949 i en mindre antiNATO-demonstration. Eftersom Trastullis död verkade ganska meningslös efter det att opinionen svängt och blivit NATO vänlig, flyttade folkminnet Trastullis död till 1953, då stora protestdemonstrationer pågick mot avskedandet av 2000 personer från stålfabriken i Terni. Trastullis död kopplades till en meningsgivande kontext och Trastulli blev ihågkommen som en arbetarhjälte.

11 Se Unchronic Dreams: Working - Class Memory and Possible Worlds, i Portelli, 1991. 
man bedömer situationen och väljer och vrakar bland de föreställda möjligheterna. Minnena väljs ur den nästkommande berättelsens perspektiv, dess intentionalitet och komplexa logiska konsistens. Man väljer ut de verklighetsbrickor som bedöms som lämpliga för den givna situationen och berättelsen konstrueras med dessa. Intervjuarens närvaro är en sådan bricka och om denna närvaro gör sig gällande på rätt sätt kan den påverka berättelsens konstruktion mot en högre grad av objektivitet.

Genom att acceptera muntlig historia bevisar historievetenskapen att den följer den allmänvetenskapliga utvecklingen. Äntligen ser och accepterar den att fakta också konstrueras; verkligheten i människans värld är ingenting annat än en ständigt växlande relation mellan denna skapade värld och den skapande individen. Muntlig historia fokuserar på individen i denna relation. Denna infallsvinkel måste sedan speglas mot ett av historikern konstruerat - ärligt redovisat och accepterat - bakgrunds- och tolkningsmönster som förklarar och höjer den enskilda relationen till en mer generell nivå. Då får vi - enlig min mening - en beskrivning och tolkning som i stort sett motsvarar dagens vetenskapskriterier.

\section{Muntlig historia som metod}

Den nya vetenskapsfilosofin beredde vägen och den muntliga historien kunde tåga in i vetenskapernas finrum. Rätt använd och med den rätta inställningen är muntlig historia lika vetenskaplig som vilken annan historieskrivning som helst. Den är dock inte ägnad att slå fast fakta, utan beskriver hur fakta skapas, tolkas och skapas igen - på mikronivån, men med makroperspektiv. Den behandlar fakta på ett nytt sätt men svarar på samma frågor och måste ställas inför samma källkritik som den klassiska historieskrivningen när den konstruerar sin faktabakgrund och sitt tolkningsmönster. Muntlig historia förenar på det sättet de båda stora perspektiven som på 1900-talet utkristalliserades i Europa: positivism och hermeneutik, dock på ett nytt, relativistiskt men också sanningssökande synsätt som ger fullvärdig plats och tar hänsyn till både aktör och struktur. Denna helhetssyn är en nödvändighet när man skriver muntlig historia och alla historiker som använder den muntliga historiska metoden har den, mer eller mindre.

Ur metodologisk synpunkt ställer dock den muntliga historien många svåra frågor och måste svara på en rad kritiska frågor från de mer traditionella historikerna. Ronald G. Grele sammanfattar denna kritik "into three categories; interviewing, research standards for preparation, and questions of historical methodology"12

Saken underlättas inte av det faktum att vi måste erkänna att "a human beings past experience is what he or she makes of it before the historian begins to interpret it." ${ }^{13}$ Detta medför en dubbel biasrisk. Denna dubbla biasrisk styr uppmärksamheten på behovet av ett angrepp på bred front när man börjar analysera och kommentera intervjun - och skriva historia. "Historical thinking means nothing else than interpreting all the available evidence with maximum degree of critical skill" ${ }^{14}$ skrev R.G. Collingwoods och även en muntlig historiker

12 Grele 1975:130.

13 Yows 1994: 21.

14 Citerat ur Yows, 1994:22. 
måste hålla med honom. Samma tänkande som för vanlig källkritik måste alltså tillämpas även i muntlig historia. Men det måste kompletteras med funderingar om hur social och individuell kunskap formas och används för handlingens och identitetens utformning.

Samtidigt måste vi fundera på vad som är viktigt att ta reda på: situationen eller processen. Eller med andra ord: Vill vi förklara eller beskriva det som har hänt, vill vi beskriva, räcker det att ta reda på fakta. Tror vi att dessa finns som rena saker som har samma intersubjektiva innehåll både i synkron och diakron mening och anser vi att historievetenskapens sak är att kunna avgränsa och beskriva dessa, ja då förkastar man muntlig historia, ty muntlig historia täcker fakta med förklaringar. Men om vi inte nöjer oss med rena fakta utan vill ta reda på hur folk använder - eller kanske rentav tillverkar - det som sedan kallas fakta, då är vi intresserade av muntlig historia. Och muntlig historia kan, paradoxalt nog, bli en bra väg även mot det som är den objektiva historiens ambition: intersubjektivitet. Ty användning eller tillverkning av fakta sker för att intersubjektivt underbygga en berättelse, som ger en svarsvariant på den processuella varför-frågan både för berättaren och för historikern. Vilka fakta för vilka berättelser? Vilka är de fakta som anses göra berättelsen trovärdig? Hur ska de ordnas och tilllämpas? Sättet på vilket strukturering av fakta sker i en berättelse säger oftast mer om intersubjektivitetens tidsbundna krav än faktamängden. Minnet är bristfälligt när det gäller fakta, det är mycket mindre bristfälligt när det gäller kriterierna för trovärdighet. Berättelsen måste vara trovärdig och på så sätt avslöjar den gällande verklighetsuppfattningen. Därmed hjälper den oss att förstå hur och varför saker har skett så som de gjort. Den visar hur händelserna tolkades och sattes i ett sammanhang och den visar den konstruerade kausaliteten som kopplar ihop fakta och gör dem meningsfulla. ${ }^{15}$ Just därför skriver Alistair Thompson: "Among the most obvious sources for contemporary history are the memories of people who have lived through past events". ${ }^{16}$

\section{Forskaren och den intervjuade}

Inom muntlig historia är det viktigt att inse att historikern och den intervjuade ofta har olika uppfattningar om vad intervjun tjänar till. Den intervjuade vill nästan alltid framföra något utöver innehållet. Berättaren hoppar mellan tider, glömmer ange tidpunkter, höjer och sänker rösten osv., ty genom berättelsen klagar, anklagar och dömer han. Han gör en handling av berättelsen och ger en mening åt det som har hänt. Denna handlingsaspekt måste omtolkas av historikern till en sammanhängande historia, som avslöjar det som finns bakom berättarens intentionalitet. Alessandro Portelli skriver:

Historians may be interested in reconstructing the past; narrators are interested in projecting an image. Thus, historians often strive for a linear, chronological sequence; speakers may be more

15 Sjuttonhundratalsfilosofen David Hume analyserade orsaksbegreppet (kausalitet) som en konstant förbindelse mellan fenomen som berör varandra i tid och rum. Hans slutsats är att påståenden om orsaker, vare sig det gäller enskilda fall eller t.ex. att allt måste ha en orsak, bygger varken på objektiva egenskaper hos verkligheten eller på förnuftssanningar, utan bara på en psykologisk vana vars ursprung ligger i det mänskliga tänkandet Se Nationalencyklopedin, www.ne.se/jsp/search/article.jsp?i_art_ id=206138\&i_word=hume.

16 I artikeln Unreliable Memories? The use and abuse of Oral History, i Lamont, 1998. 
interested in pursuing and gathering together bundles of meaning, relationships and themes, across the linear span of their lifetimes. ${ }^{17}$

Denna skenbara inkonsekvens i berättelsen ställer samtidigt en viktig fråga till metodologin: Ska intervjuaren bryta in och försöka hålla berättelsen inom huvudtemats ramar och se till att ingenting glöms bort eller ska han låta berättaren tala fritt och rekonstruera historien bakifrån? Jag anser att det är viktigt att bryta in bara om det är absolut nödvändigt och jag är inte överens med författaren, när hon skriver att man ska försöka få in berättelsen i en tids- och rumslig ram. Viktiga delar kan försvinna medan den intervjuade funderar om tidsangivelser och berättelsen bryts av sådana frågor. Den påtvingade kronologiska rationaliteten kan sopa bort möjligheten att se förklaringsmekanismerna och orsakssambanden som avslöjar den bakomliggande verklighetsuppfattningen hos den intervjuade.

Forskaren som använder muntlig historia måste vara uppmärksam på en rad angelägna frågor om relationen som byggs upp mellan honom och den intervjuade. Ras, etnicitet, kön, klass, eller kulturella skillnader kan påverka intervjuns innehåll och riktning. Ifråga om könets betydelse kan till exempel skillnaden i hur kvinnor och män ser på intervjurelationen påverka intervjuresultaten. Medan kvinnor i allmänhet är mer måna om att bygga upp och bevara relationen och inte säger emot, ser män ofta intervjusituationen som en fråga om makt och hierarki. Resultatet blir att män inte ger svaghetsavslöjande svar. Att intervjuaren förstår detta, att han eller hon alltid har en självreflekterande attityd kan vara avgörande för en lyckad intervju. Även förståelsen av de icke språkliga kommunikationskoderna är av central betydelse för att intervjun ska ge goda resultat. Allt detta förutsätter mycket grundläggande kunskaper om den intervjuade. Oftast behöver man vara en kulturell insider för att göra den bästa tolkningen av det som framkommit i intervjuprocessen. Slutsatsen borde vara att i nästan alla intervjusituationerna är det bäst om intervjuaren har samma bakgrund som den intervjuade.

\section{Muntlig historia och behovet av interdisciplinär kunskap}

Muntlig historia ställs också inför andra teoretiska och metodologiska frågor som i högsta grad är känsliga för den klassiska historievetenskapens krav. Det främsta argumentet mot muntlig historia är dess opålitlighet, vilket rör den andra aspekten som Ronald Grele skriver om: research standards. Denna fråga handlar om det höga kravet på metod och som en muntlig historiker ställs inför.

Minnet är inte bristfälligt bara ur glömskans synpunkt. Tänker vi på hur minnet fungerar inser vi att det lägger till saker, förändrar evenemangsförlopp eller ändrar datum för evenemang. Det knyter samman eller drar ihop händelser som utspelade sig vid olika tidpunkter osv. ${ }^{18}$ Ur dessa komprimerade och ofta symbolladdade berättelser måste historikern skala fram en pålitlig historia. Berättelsen som föds ur intervjun med historikerns hjälp blir inte ägnad åt att framställa en verifierbar sann historia. Pålitligheten kommer inte därifrån. För att denna historia ska anses som pålitlig krävs framför allt en historiesyn som sätter människan 17 Portelli, 1991:75.

18 Muntlig historia ställer alltså krav på en tydligare kunskapsteori och på kunskaper i socialpsykologi och även psykologi. 
och inte fakta i berättelsens centrum. Detta synsätt är mycket mer komplext och ställer höga krav både på metod och kunskap. Förutom en bred historisk bakgrundskunskap kräver den en beredskap att placera, värdera och omvärdera sig själv i intervjusituationen ur både psykologisk och filosofisk synpunkt.

\section{Hermeneutiken i muntlig historia}

Många historiker tycker att skrivna källor är mer pålitliga än muntliga. Jag anser emellertid att även vid skrivandet är tanken styrd av andra saker än viljan till objektiv framställning. Vi vill föra vidare meningsfulla saker och bli förstådda. Vi skriver med tanke på en dialog med den framtida läsaren och vi vill bli förstådda på ett visst sätt! Denna vilja att bli förstådd på ett visst sätt styr den skriftliga framställningen lika mycket som den muntliga. Den skriftliga berättelsen kan t.o.m. bli sämre än den muntliga genom att vi försöker ekonomisera framställningen: göra oss förstådda med så få ord som möjligt. Detta leder till förenkling och ofta döljer resonemangets väg mot slutsatsen. I ett muntligt sammanhang framträder vägen tydligt eller - om den inte framträder - kan historikern ställa följdfrågor som tvingar fram den. Detta är kanske historikerns viktigaste roll i muntlig historia.

Muntlig historia är enlig min mening berättelser om hur historia fungerar och får betydelse för människor, hur den tolkas och blir en ram för förståelsen. Eftersom fakta alltid upplevs, bearbetas och tolkas har de ingen självständig existens på annat sätt än som en ganska lös kommunikativ medelpunkt. Upplevelsen är nästan mer konkret. Eftersom muntlig historia sysslar just med upplevelser lyfter den historievetenskapen till en ny nivå som är närmare förståelsen av hur fakta verkar, hur fakta blir verklig och verksam genom tolkning och handling.

Det stora problemet som historikern måste brottas med, om han vill använda intervjun för en historisk rekonstruktion, är den höga graden av instabil subjektivitet $\mathrm{i}$ tolkningen. En trippelhermeneutik skulle man kunna säga. Redan när handlingen som det berättas om utspelades, var den ett resultat av en tolkning av en situation. Vi har alltså händelsen som ursprunglig ram. Den omtolkas senare i en allt bredare ram inom en levnadsberättelse som ger händelsen mening. Denna levnadsberättelse är dock högst situationellt betingad. Berättaren ljuger inte; han anpassar berättelsen till den givna situationen så som den tolkas av honom. Då får vi trippelhermeneutikens sista led: legitimeringen - inom den givna situationen.

\section{Myterna och muntlig historia}

Muntlig historia kan ge nyckeln till förståelsen av hur historia fungerar som legitimerande och identitetsgivande konstruktion. Människan konstruerar en myt som sedan ligger till grund för upplevelsen som i sin tur ligger till grund för vidare aktioner... Här menar jag att det för initieringen och motiveringen av varje handling skapas en sammanhängande berättelse - en myt. 


\section{Berättelsernas eviga mallar}

När vi berättar använder vi - medvetet eller omedvetet - färdiga mallar och stereotypier som skapar berättelsens intersubjektivitet. Det handlar också om människans sätt att omkonstruera verkligheten efter egna värdeskalor. Vilka mallar och stereotypier som används i berättelserna kan dock öppna vägen mot en bättre förståelse av de storsociala händelserna också.

Krig är inget enmansföretag, och inte heller logiskt ur individens synpunkt. Det skulle vi kunna invända t.ex. mot ett försök att genom muntlig historia förklara kriget som företeelse, ty muntlig historia missar grundläggande strukturella sanningar som inte kan nås genom individen. Men så enkelt är det inte. Att vi individer i stora skaror gör oss skyldiga till samma fel beror på våra identiteter och tillhöranden. $V i$ och $d e$ är oftast den grundläggande strukturerande principen som skapar vår identitet och återfinns i alla berättelserna. Långlivade symboler, knutna till färdiga mallar används för att beskriva gemenskapen, mallar som är tillräckligt gamla för att erkännas och delas intuitivt av alla som tillhör den. Kunskap om de mallar som ligger till grund för dessa grundläggande strukturerande principer kan berätta mer om perioden än en verklighetstrogen beskrivning. De visar vilka tankebrickorna var som användes för att ge en gemensam grupprepresentativ tolkning av den s.k. verkligheten. Tillhörigheter och uteslutningar beror på om man delar eller icke delar dessa mallar och symboler. Och man för krig när meningen i dessa gemenskapskapande symboler och mallar är hotade. I hur folk berättar och förklarar sina liv - eller historiska händelser - kan man ofta spåra dessa identitetsskapande symboler och mallar, som förklarar individens deltagande $\mathrm{i}$ den storsociala handlingen. Muntlig historia öppnar på så sätt, trots sin opålitlighet, nya nödvändiga vägar för att förstå de stora sammanhangen.

\section{Att förstå tystnaden}

Om muntlig historia används med rätt kunskapsbakgrund erbjuder den även andra möjligheter till ökad förståelse av historien. När vi lyssnar på folk är det ofta viktigare att ta reda på vad de inte berättar än vad de berättar. Alice Kessler Harris menar att "often what's left out is more significant then what's put in." ${ }^{19}$ Hon säger att det som det hålls tyst om i intervjun ofta säger mer om människan och den kultur i vilken händelserna utspelat sig än det som återges exakt. Samtidigt kan tystnaden visa hur händelser som verkar viktiga för historikerns tillbakablick och rekonstruktion av samtiden behandlades som obetydliga och bortglömda. Kunskap om denna felaktiga logik är i allra högsta grad viktig för att kunna få en mer verklighetstrogen bild av den historiska period som man studerar. Det kan till exempel förklara hur principiellt sett förhatliga regimer kan överleva. De förbisågs och glömdes bort i vardagslivet, som Luisa Passerini visar i sin på muntlig historia byggda studie av vardagslivet och fascismen i Turin i norra Italien. ${ }^{20}$ Medan de flesta historieböcker handlar om fascismen under denna period, levde majoriteten av italienare på något sätt utanför den bild som förmedlas i dessa böcker. Systemet som skulle förklara mellankrigstiden i Italien fanns inte i de flesta italienares vardagsliv. Detta förklarar kanske varför våldsbaserade regimer så lätt faller

19 Grele 1985:69.

20 Passerini, 1992. 
när deras våldsresurser inte längre räcker till för att upprätthålla sin makt. De hålls utanför vardagslivet och detta gör att de inte får något stöd när de faller. De klassiska metoderna räcker inte för att komma så nära historien.

\section{Berättelsen som metafor}

Vissa berättelser kan fungera som metaforer för hela världsuppfattningar eller värdesystem. Det är viktigt att kunna tyda dem för att förstå människors handlingar i givna situationer. "Myth is a fundamental component of human thought" skriver Paul Thompson och Raphael Samuel, och med hänvisning till dagens händelser i Irland, Libanon osv: ”. . myth has lost neither its imaginative purchase nor its living power as a historical force today." ${ }^{21}$ Man kan bara hålla med dem. De slår också fast den muntliga historiens roll i förståelsen av hur verkligheten uppfattas och ofta omvandlas till en metafor som erbjuds som ett instrument för en bättre insikt:

We can observe the displacements, omissions and reinterpretations through which myths in personal and collective memory take shape ...we must look at life stories in this light. They should bee seen not as blurred experience, as disorderly masses of fragments, but as shaped accounts in which some incidents were dramatised, others contextualized, yet others passed over in silence, trough a process of narrative shaping in which both conscious and unconscious, myth and reality, played significant parts $\ldots{ }^{22}$

Muntlig historia ger möjlighet att se och analysera hur "... personal history is formed and shaped by symbolic notions of the past" och ger, som jag tidigare sagt, tillgång till att förstå hur kunskap och identitet byggs upp inte på reella grunder utan på en realitet filtrerad eller skapad av mytens och metaforens logik. ${ }^{23}$

Myter är idealbildande; både bakåt, för att förklara "vad som hände" eller "varför gjorde vi så?", men också framåt, som ideal för hur världen ska se ut och för hur vi ska bete oss, myten om det kvinnliga eller manliga idealet, om hur en mor ska vara osv. Detta är vad som driver människors handlingar, och det som kanske har den största historieskapande effekten. Men den historiker som alltför länge skolats i faktasökande vetenskapliga värderingar kan ofta missa detta. Samuel och Thompson utrycker denna oro när de skriver om nationella myter:

As historians, perhaps taking to much in our culture for granted, and certainly sceptical of the origins of these national myths, we risk missing their real historical significance. For such constructed myths have an extraordinary power to rally whether at the ballot box or on the battlefield ... national myths and the sense of national history which they help to build also raise fundamental questions of just who belongs and who does not. Time and again, in rallying solidarity they also exclude, and persecute the excluded. ${ }^{24}$ As western historians trained in a rationalistic tradition of cause and effect it is not easy for us to evaluate the power of symbols, the force of illusion. Yet it is not the less real for that. ${ }^{25}$

21 Raphael \& Thompson, 1990:4.

22 Raphael \& Thompson, 1990:5.

23 Raphael \& Thompson, 1990:6.

24 Om nationalmyten och nationalkänslan saknas ersätts den av andra myter, som förmodligen föregick nationalmyten, som t.ex. den om familjetradition, förfäderna eller religiösa myter. Detta behov av identitets- sammanhållande myter visas övertygande i.

25 Samuel \& Thompson, 1990:18-19. 
"Many historians live by the myth of realism" skriver Elisabeth Tonkin och jag kan bara hålla med henne. Liksom när hon skriver att 'I write on 'representations of pastness' instead of 'history' because that is what all histories must be. They are chains of words, either spoken or written, ordered in patterns of discourse that represent events." ${ }^{26}$

\section{The Myths We Live by}

Folk använder vedertagna stereotypier i sina livshistorier för att bygga upp - som Henri Tajfel skulle utrycka det - positiva sociala identiteter. ${ }^{27}$ Dessa är inga målmedvetna konstruktioner utan val mellan de tillgängliga förklaringsbrickorna. Ett bra exempel är utvecklingsmyten. Den är så grundmurat inbyggd i det västerländska tänkandet att folk berättar nästan alltid om sina liv som en uppåtgående process. Många affärsmäns livshistorier börjar - skriver Jean Peneff - med myten om en fattig barndom. Ju lägre man startar desto större är uppgången. Och medan början är någon annans förtjänst, är uppgången deras egen. ${ }^{28}$

Mytkonstruktionen härstammar ur ett grundläggande mänskligt behov att förklara och kontrollera omgivningen. Den är en typisk metod också för att ge mening åt den obegripliga tillvaron. Även om myten är imaginär har den en skapande kraft som omformar och förändrar den mänskliga verkligheten så att den blir begriplig. Denna nya verklighet ligger sedan till grund för lagar och regler som styr människans vardagliga tillvaro och påverkar hennes syn och tankar. Och för vardagslivets människa blir dessa regler och lagar långt viktigare och mer reella än någon ontologisk sanning om världens beskaffenhet. Det viktiga är att denna sanning som myten skapar har en mening både för världen och människan. Samtidigt ger den människan en identitet som motstår det dagliga livets föränderlighet och leder henne tillbaka till ett väsen runt vilken livets tillfälligheter samlas.

I myten får historia och framtid sin mening och vardagens meningslöshet upplöses i det egna livets meningsgivande mytiska berättelse. Dess funktion är ofta att ge hopp i hopplösa situationer. Dessa grundläggande drag utgör egentligen The Myths We Live by. ${ }^{29}$ Muntlig historia kan öppna vägen för att se deras verkan.

Louisa Passerini tvekar inte att använda sig av Jung och knyta historien till arketypiska gestalter eller tankemönster vid analysen av intervjun. Hon citerar James Hillmann och skriver att muntlig historia öppnar vägen till att "rediscover history as recorder of the meaningful." ${ }^{30}$ Hon skriver också att muntlig historia "... force us ... to reflect on our fundamental habits of thought." ${ }^{31}$ Detta är verkligen något som dagens historiker behöver göra. Vi förmår ännu inte hantera den relativa irrationaliteten som verkar på individnivå och koppla den till strukturernas nödvändiga rationalitet.

26 Benmaior \& Skotnes, 1994:27.

27 Se Henri Taifels teori om positiva sociala identiteter presenterad i introduktionskapitlet i Bourhis, \& Leyens, 1994, och i artikeln av Cioldi \& Doise i samma bok..

28 Se Jean Peneffs artikel, Myths in life stories, i Samuel \& Thompson, 1990.

29 Samuel \& Thompson, 1990.

30 Passerini, 1992:56-57.

31 I artikeln Work Ideology and Working Class Attitudes to Fascism, Thompson, 1982:55. 


\section{Att använda muntlig historia}

Our Common History är kanske en av de bästa böckerna om muntlig historia som jag har läst. ${ }^{32}$ Den visar historikernas väg mot den nya metoden, men samtidigt speglar den hur svårt det var för vissa att acceptera muntlig historia som metod och hur de brottades med frågorna som denna, då nya, metod ställde. Ett tydligt exempel på denna brottning och på historikerns utveckling i den här processen ges av Lutz Niethammer. Han upptäckte den stora diskrepansen mellan hur historiker ofta uppvuxna i medelklassfamiljer och arbetare tänker: "Through the interviews we were introduced to new ways of thinking and acting often anathema to our petit-bourgeois habits and style." ${ }^{33}$ Muntlig historia blev för honom en metod att öppna kommunikationen mellan dessa två världar. Upptäckten av denna nya möjlighet avlägsnade dock inte misstänksamheten. Källorna verkade opålitliga och förvirrande för den traditionellt tänkande historikern: "... finally I ended up by collecting five substantially different of one and the same story about a major event, all by one and the same author...". ${ }^{34}$ Ändå blev de mycket värdefulla ur flera andra synpunkter. Den ena synpunkten var egentligen en ren fakta synpunkt. Niethammer skriver om reorganiseringen av livet i Tyskland efter kriget. I denna reorganisering hade de s.k. working-klass liberation commitees en viktig roll, men de upplöstes av ockupationsmakterna, och spåren sopades igen av deras agenter. Det enda som återstod var några få intetsägande dokument. Den enda lösningen för att rekonstruera och skriva dessa kommittéers historia var att använda muntliga källor.

En annan viktig aspekt som talade för den nya metoden var upptäckten att intervjuerna var viktiga även för att kunna tolka de få skrivna källorna: "these stories ... opened our eyes to how these sources might be interpreted." ${ }^{35}$ Inte bara tolkningen utan också sättet att fråga förändrades genom kontakten med människorna, med den levande historien. Niethammers metodiska slutsats sammanfattats på följande sätt: "oral history taught us how to ask new questions and proved to be a training ground for imaginative interpretation." 36

Att förstå hur människor hanterar det dagliga slitet och hur detta leder till uppror och revolution är något som ofta överskrider faktainsamlarens möjligheter. Muntlig historia kan föra oss närmare denna förståelse. Att se vilka människors "main areas of concern" var och hur dessa förändrades eller medvetandegjordes under påverkan av yttre händelser, är möjligt bara genom att göra en samlad muntlig dokumentation av flera olika intervjuer och sedan sammanställa alla varianter av samma berättelse. ${ }^{37}$

Inom muntlig historia finns dock några specifika fallgropar som Luisa Passerini varnar oss för: "These are firstly to use oral sources in a mainly or entirely factual way, simply to convey or confirm evidence on particular events: and secondly, to evade discussion of the problem which they pose in relation to wider historical interpretation, protecting but in the

32 Thompson, 1982.

33 Se artikeln Oral history as a Channels of Communication between Workers and Historians, i Thompson, 1982.

34 Ibidem, s. 24

35 Ibidem, s. 25

36 Ibidem, s. 27.

37 Se artikeln av Borderias \& Vilanova, Memories of Hope and Defeat: Catalan Miners and Fishermen under the Second Spanish Republic 1931 - 9, i Thompson \& Burchardt, 1982. 
same way stifling oral history within a ghetto of its own." ${ }^{38}$ Det är uppenbart att Passerini menar att det är vanskligt att leta svar på frågor om exakt kronologi och ren objektivitet med den muntlig historiska metoden. Det är förvisso farligt att bortse från de här frågorna och stänga in muntlig historia i ett litet fack. Muntlig historia är en metod som belyser en sida av historien, vilket förstås är långtifrån tillräckligt. Man måste kunna kommunicera med övriga metoder och kombinera resultaten. Detta underlättas inte av det faktum att muntlig historia kämpar med "major problems of conceptualisation." "39 Snarare visar det här att många av dess representanter ännu inte har förmått lämna de gamla tankebanorna. Att föra in den enskilda berättelsen, vardagslivet och individualiteten i den stora allmänna berättelsen, att svara på frågor om mening och representativitet är fortfarande svåra problem för muntlig historia. Hur historiska händelser växer fram ur vardagslivet eller hur vardagslivet hanterar dessa händelser, hur grunderna till historiens födelse och fortsatta existens skapas genom de individuella högst slumpbetingade levnadsödenas sammanflätning är problem som behöver adekvata begrepp för att kunna lösas.

Analysen av vardagslivets förfinade och oerhört påtagliga tidlighet, det känsliga spelet mellan slump och nödvändighet, mellan enskildheter och longue durée, mellan mentalitet, stereotyper och konkreta händelser kräver en ny filosofi av historien, en filosofi som tillåter en glidning mellan dessa nivåer utan att skapa inkoherens.

\section{Muntlig historia och falska myter}

Ett tydligt bevis på behovet av muntlig historia är dess kapacitet att genom sin närhet till vardagslivet slå sönder vissa etablerade historiska myter. Låt oss ta som exempel Luisa Passerinis artikel om arbetarna i Turin, som visar hur den gamla historieskrivningens stereotypier - till exempel myten om den antifascistiska arbetarklassen - upplöses i vardagslivets verklighet. I sina slutsatser påstår Passerini inte att arbetarklassen blev profascist. Saken var dock inte så enkel. Det fanns även en viss accepterande av fascismen under påverkan av "defeat and acceptance and rationalization of the defeat." ${ }^{40}$ Intervjuerna visar att fascismen tog fram gamla värden som kunde skapa en konsensus som kunde dölja känslan av besegrad klass hos arbetarna. Passerini visar samtidigt att motståndet inte uppkom på det sätt som historikerna och ideologierna har talat om, alltså inte i namn av ett klassmedvetande, utan genom ett instinktivt avståndstagande från fascismens motsägelsefullhet. Det var ju fascisterna själva som inte levde upp till de värden som själva tog fram. Och här ligger - menar jag - grunden till vardagsmänniskans instinktiva avståndstagande från fascismen eller kommunismen: deras representanter ljög henne rakt upp i ansiktet. Runt principerna kunde konsensus skapas. Men inte runt representanterna. Och detta gör att Passerini hade rätt när hon skrev: "the problem of consensus under Fascism is not merely a historical question: it is also of contemporary political relevance." Av evig relevans skulle jag tillägga. En annan fråga, som fortfarande har högst relvans är: "what makes the oppressed internalise the acceptance of their dependence? What leads them to accept their oppression in cultural and psychological terms, to the point 
of even praising it and preferring it to any struggle for change?"41 Man måste fråga människorna, och lyssna på deras förklaringar, för att förstå detta. Bara genom att förstå vardagen och det vardagliga tänkandet kan man gå till botten med den historiska förståelsen.

Muntlig historia kan föra fram företeelser i ljuset, som inte kan deduceras ur analys av socioekonomiska förhållanden. Genom att skapa adekvata begrepp kan man blottlägga subjektiva tolkningar och meningar, samt förstå hur de stora händelserna omgestaltas i vardagslivets slit. Nödvändigheten att skapa begrepp inifrån det dagliga livet som speglas i intervjuerna är uppenbar när de vetenskapliga begreppen och den dagliga verkligheten som intervjuerna ofta talar om inte riktig passar ihop. ${ }^{42}$ Detta är både möjligt och nödvändigt i den muntliga historiens fall och ett absolut behov i hela historieskrivningen. Genom att föra in vardagslivet i ljuset kan man följa förändringen i de värderingar som låg till grund för de gamla sociala relationerna och se hur det nya tar form.

Att till exempel den italienska arbetarklassen splittrades av olika ideologier förklarades genom enkla och rent vardagliga resonemang som inte kan omfattas av vetenskapliga begrepp. Liliana Lanzaro visar hur lite det var som avgjorde om någon tog ställning för eller mot katoliker, för eller mot kommunister i det italienska vardagslivet. Hon visar också hur dessa vardagliga val sedan blev överideologiserade för att legitimera politikernas maktanspråk. De små ord som bidrog till splittringen växte till fakta, och verkade på ett sätt som inte gynnade arbetarklassens enhet. ${ }^{43}$

Det finns även exempel på hur historisk kontinuitet och diskontinuitet sätts under lupp med hjälp av muntlig historia. Hur folk bevarar eller förlorar sin identitet. Häpnadsväckande uppgifter kommer fram genom den muntlig historiska analysen av hur t.ex. judar och tyskar minns kriget och övergångstiden som omedelbart följde. Nästan alla intervjuade tyskar går förbi judeförföljelserna i sina levnadshistorier. Tendensen att minimera förföljelsernas betydelse och främst minnas bombardemangen och de tyska förlusterna är genomgående. Dessa tyska förluster räknas som motvikt till brotten som hade begåtts. Tyskarna hade mördat men de hade också blivit utsatta för mordiska attacker. Runt denna upplevelse solidariserar sig tyskarna efter kriget.

Judarna får plats för ett ögonblick i dessa berättelser för att sedan försvinna, utan att detta försvinnande väcker några frågor. Vad gäller tyskarnas syn på judarna under efterkrigsperioden skriver Frank Stern att: "the dividing line between the stereotypical impact before and after 1945 is very thin ... The image of the Jew as perceived by many Germans is part of the continuous mental flow from the 1930s to the 1960s." 44

I skriande kontrast mot tyskarna speglar intervjuerna med judiska överlevande den enorma, nästan slutgiltiga brytningen som inträdde i deras liv och i relationen till tyskarna efter förföljelsernas början. De rycktes upp ur sina liv och slängdes ut bland dödliga fiender utan att hinna reagera. De utplånades och deras tyska grannar tittade i bästa fall bara på - eller så

41 Båda citat ur Passerini, 1992:58.

42 Passerini, 1992:59-61.

43 Liliana Lanzaro i Passerini, 1992.

44 Frank Stern, Antagonistic memories i Passerini, 1992: 28. 
medverkade de. De få som lyckades överleva hade intrycket att leva på lånad tid. Allting förändrades och ingenting kunde någonsin bli som förut. Tyskarna blev för alltid de andra. ${ }^{45}$

\section{Muntlig historia: mer än vetenskap}

Historikern som använder sig av muntlig historia som metod ställs inför svåra val både ur metodisk, moralisk och kunskapsteoretisk synvinkel. Ett citat av Louisa Passerini som belyser detta passar bra som avslutning till denna artikel:

Memory - or better: memories - can help us find ways, in the era of the equality and cosmopolitanism, 'to participate in the other, to share his/her being other'.

$\ldots$

For us the task is to participate in different memories, to share their differences not in any way in an attempt to demonstrate their universality but rather to insist on the diversity and the plurality of memory. ${ }^{46}$

Denna inlevelse i den andres värld och förståelsen av de enskildes autonomi och mångfalden i det universala är en uppgift som är lika viktig som allt annat i historievetenskapen. Muntlig historia har - trots sina svårigheter - visat sig kunna lösa denna uppgift. Den har visat sig vara den bästa vetenskapliga metoden både för att komma åt denna pluralitet och för att relatera den till den skenbara enhet och kontinuitet som strukturerna uppvisar. Muntlig historia är också något mer: den kan öppna våra känslor och tillåta oss komma närmare den känslomässiga bakgrunden till det som har hänt. Den berör oss. När den lyckas, då är denna historieskrivning lite mer än vetenskap.

\section{Referenser}

Benmaior \& Skotnes, Migration and Identity, New York, 1994.

Bertaux, Daniel, Biography and Society, Beverly Hills, 1983.

Bourhis \& Leyens, red., Stéréotypes, discrimination et relation intergroupes, Liège, 1994.

Chalmers, Allan: Vad är vetenskap egentligen, Stockholm, 1995.

Dunaway \& Baum, red., Oral History: An Interdisciplinary Anthology, London, 1996.

Establet, Roger, Comment peut-on ètre Français?, Paris, 1997.

Grele, Ronald J., Envelopes of Sound, Chicago, 1985.

Heisenberg, Werner, Delen och helheten, Stockholm, 1993.

Hirsch, Herberth, Genocide and the Politics of Memory, London, 1995.

Kuhn, Thomas, The Structure of Scientific Revolution, Chicago, 1996.

Lakatos, Imre, Proofs and Refutations, Cambridge, 1976.

Lakatos, Imre, The Methodology of Scientific Research Programmes: Philosophical Papers Volume 1., Cambridge, 1977.

Lamont, William, red., Historical controversies and historians, London, 1998.

Passerini, Luisa, Memory and totalitarianism, Oxford, 1992.

Perks, Robert \& Thomson, Alistair, red., The oral history reader, London, 1998.

45 Ibidem, 42.

46 Passerini, 1992: 18. 
Portelli, Allessandro, The Death of Luigi Trastulli ... Form and meaning in Oral History, New York, 1991.

Ritchie, Donald A., Doing Oral History, New York, 1995.

Samuel \& Thompson, red., The Myths We Live by, London, 1990.

Stave \& Sutherland \& Salerno red., From the Old Country, Hanover, New England, 1999.

Thompson \& Burchardt, red., Our Common History: the transformation of Europe, London, 1982.

Vansina, Jan, Oral Tradition, Chicago, 1965.

Yow, Valerie Raleig, Recording Oral History, London, 1994. 